УДК 347.212 .1

$10.17213 / 2075-2067-2019-4-145-149$

\title{
АКТУАЛЬНЫЕ ПРОБЛЕМЫ ЗАЩИТЫ ДЕЛОВОЙ РЕПУТАЦИИ ГРАЖДАН И ЮРИДИЧЕСКИХ ЛИЦ
}

\section{(C) 2019 г. T. В. Записная}

\section{Южнн-Российский государственный политехнический университет (НПИ), 2. Новочеркасск}

Статья посвящена анализу судебных актов, принятых по делу о защите деловой репутации Лапина Максимилиана Александровича. Данные акты привлекли внимание автора в связи с тем, что суд, отказывая в защите деловой репутации, использовал достаточно спорные суждения. Решение по делу М. А. Лапина возвращчает к обсуждению ряда дискуссионных вопросов, таких как: какая деловая репутащия подлежит защите, какую репутацию следует считать отрицательной, что такое уровень деловой репутации, как можно определить момент, когда деловая репутация считается сформировавщейся.

Ключевые слова: деловая репутация; утрата доверия к деловой репутации; предмет доказывания; честь и доброе имя; положительная деловая репутация; уровень деловой репутащии; порочащие сведения.

The article is devoted to the analysis of judicial acts adopted in the case of protection of business reputation of Lapin Maximilian Alexandrovich. These acts attracted the attention of the author due to the fact that the court, refusing to protect business reputation, used quite controversial judgments. The decision in the case of M. A. Lapin returns to the discussion of a number of controversial issues, such as: what business reputation is subject to protection, what reputation should be considered negative, what is the level of business reputation, how can you determine the moment when business reputation is considered to be formed.

Key words: business reputation; loss of confidence in business reputation; the subject of proof; honor and good name; positive business reputation; the level of business reputation; discrediting information.

В течение 2018 года юридическая общественность с определенным интересом наблюдала за делом между индивидуальным предпринимателем Лапиным Максимилианом Александровичем, который обратился в арбитражный суд с иском о защите деловой репутации, и Обществом с ограниченной ответственностью «Реалист», а также Общественным уполномоченным по правам ребенка в Санкт-Петербурге Баранец Ольгой Николаевной, выступившими ответчиками [5]. Вынесенные по данном делу судебные акты озадачили многих юристов.
Отказывая в иске, Арбитражный суд города Санкт-Петербурга и Ленинградской области в том числе указал, что защите подлежит только положительная деловая репутация, которой, по мнению суда, истец не обладает. Но самое главное заключается в том, по каким критериям суд в данном случае оценил деловую репутацию ИП М.А. Лапина как отрицательную и тем самым не подлежащую судебной защите.

В законодательстве Российской Федерации отсутствует законодательное определение таких понятий, как «честь», «достоинство» 
и «деловая репутация». Однако содержанию этих нематериальных благ уделялось значительное внимание в научной литературе. По мнению Г.Ю. Мордохова, деловая репутация представляет собой уникальную, индивидуализирующую субъект предпринимательской деятельности характеристику, обладающую свойством изменчивости, уникальный информационный образ, который позволяет определять отношение неограниченного круга участников рынка к субъекту предпринимательской деятельности как с положительной, так и с отрицательной стороны [7].

Изначально в публикациях, посвященных деловой репутации юридического лица, очень редко встречалось деление репутации на положительную и отрицательную. Вопросом определения отрицательной деловой репутации никто не задавался, понимая ее как антагониста положительной. Но принятое решение по иску М.А. Лапина требует уточнения, что же следует понимать под отрицательной деловой репутацией.

Положительная деловая репутация складывается в результате добросовестного поведения участников делового оборота. В первую очередь, деятельность должна быть законной. Вторым значимым критерием, формирующим положительную деловую репутацию, является поведение хозяйствующего субъекта по исполнению им взятых на себя обязательств в сфере предпринимательской деятельности.

Однако, Арбитражный суд города СанктПетербурга и Ленинградской области оценивал деятельность истца не с точки зрения добросовестности его поведения в рамках конкретной сферы деятельности, а с точки зрения морали и нравственности. По мнению суда, деловая репутация истца ИП М.А. Лапина создана «в иной культурологической среде, не принимающей систему ценностей, несвойственных культурно-духовным традициям России, имеющим глубокие исторические корни и передающимся из поколения в поколение, составляющим основы цивилизационной самобытности российского государства, к которым, в частности, относится: приоритет духовного над материальным, семья, нормы морали и нравственности», поэтому является отрицательной и не подлежит судебной защите. В данном случае речь идет скорее не культурологической среде, а о социокультурной среде. Социокультурная среда - совокупность сложившихся, типичных для данного ареала духовных ценностей, обычаев, традиций, менталитета людей, проявляющихся в устойчивых формах их жизнедеятельности, взятых в единстве с социальными условиями бытия [10]. Однако в своем решении суд указывает, что деловая репутация - это оценка профессиональных качеств конкретного лица. Свое видение деловой репутации юридического лица Верховный Суд Российской Федерации отобразил в Определении от 26 октября 2015 года по делу №307-ЭС15-5345, А56-17708/2014 [3], указав, что деловая репутация организации как профессиональная репутация, которая заработана в среде аналогичных профессионалов (например, коммерсантов), а также в среде лиц, на которых направлена деятельность организации (например, потребителей товаров, работ, услуг), включает в себя профессиональную репутацию как самой организации, так и ее руководителей. Вопрос о тождественности профессиональной и деловой репутации физического лица является дискуссионным, так как ряд авторов предлагают их различать [8].

Деятельность, осуществляемая ИП М.А. Лапиным (продажа интим-товаров), является законной, хотя, возможно, и осуждается определенной частью российского общества. По данным компании Fun Factory, российский рынок интим-товаров - крупнейший в Восточной Европе, по объему он сопоставим с рынками Великобритании и Франции [9]. Данная отрасль начала свое формирование в 1990-х годов, пережила два экономических кризиса, в настоящее время наращивает свое присутствие в среде интернет-продаж. По оценкам экспертов, емкость национального рынка интим-товаров оценивается в 25 млрд. руб. На рынке действует несколько крупных оптовых игроков, развивается розничная сеть. Также стоит отметить, что данная сфера бизнеса является очень сложной с точки зрения маркетинга, поэтому, чтобы закрепиться в данном сегменте рынка, необходимо приложить значительные усилия. Однако, арбитражный суд города Санкт-Петербурга и Ленинградской области вместо того, чтобы оценить 
деловую репутацию М.А. Лапина в среде предпринимателей, а также потребителей его товаров, оценил ее с точки зрения общественной морали и нравственности, традиционных, духовных и семейных ценностей, исторически сложившихся в российском обществе. Соотношение бизнеса и морали имеет вид дилеммы. Мораль в бизнесе проявляется в виде безукоснительного соблюдения взятых на себя обязательств, качества продукции, в свободе конкуренции, в свободе информации. Однозначно аморальным является незаконный бизнес. Определение деловой репутации М.А. Лапина как отрицательной арбитражный суд вывел через оценку его бизнеса как аморального с точки зрения духовных и семейных ценностей, а также морали в широком смысле слова. Такой подход следует признать неправильным. В данном контексте все участники рынка продажи интим-товаров не обладают положительной деловой репутацией, так как их бизнес аморален с позиции определенной части общества. На наш взгляд, при оценке деловой репутации субъекта предпринимательства должны применять критерии деловой этики, но не морали и нравственности в широком их понимании.

Еще один вопрос перед юристами поставило уже Постановление Тринадцатого арбитражного апелляционного суда по этому же делу, в котором указано, что «истцом в материалы дела не представлено доказательств уровня деловой репутации истца применительно к спорному виду деятельности на момент спорных публикаций» [4]. Вопрос заключается в том, что понимать под «уровнем деловой репутации»?

Если обратиться к Постановлению Пленума Верховного Суда РФ от 24 февраля 2005 года №3, то в нем обращается внимание судов, что основными фактами, которые необходимо доказать, являются факт распространения ответчиком сведений об истце, порочащий характер этих сведений и несоответствие их действительности [1]. Основная дискуссия на тот момент развернулась вокруг проблемы, какие сведения считать порочащими и какими доказательствами это доказывать. Перелом в судебной практике произошел с принятием Постановления Президиума ВАС РФ от 17 июля 2012 года
№17528/11 [2], которое существенным образом поменяло представление о предмете доказывания по делам о защите деловой репутации юридического лица. До принятия этого судебного акта, по мнению большинства авторов, презюмировлось умаление деловой репутации вследствие распространения сведений, порочащих деловую репутацию. Однако Президиум ВАС РФ рассудил подругому и обязал доказывать факт умаления деловой репутации, причинно-следственную связь между противоправными действиями и наступившими неблагоприятными последствиями в виде умаления деловой репутации, а также факт наличия этой самой деловой репутации. К тому же деловая репутация не просто должна быть, а должна быть сформированной. Следует согласиться с мнением большого числа авторов, что принятие данного Постановления существенно изменило подход к формированию предмета доказывания по делам о защите деловой репутации юридического лица, тем самым сделав такую защиту очень затруднительной.

В доктрине немедленно развернулась дискуссия, какую репутацию можно считать сформировавшейся. Е.В. Гаврилов считает, что деловая репутация юридического лица появляется одновременно с его созданием (государственной регистрацией), а сформированная деловая репутация в различных сферах деловых отношений создается годами, подтверждается временем [6]. А.О. Эрделевский, говоря о только что созданных юридических лицах, отмечает, что если оно еще не приступило к осуществлению своей деятельности, у него нет ни положительной, ни отрицательной репутации, она находится на нулевом уровне, но даже в этот момент распространение ложных порочащих сведений может превратить деловую репутацию из нулевой в отрицательную [11].

Исходя из пункта 5 статьи 10 Гражданского кодекса Российской Федерации, добросовестность участников гражданских правоотношений и разумность их действий предполагаются. Таким образом, вновь образованное юридическое лицо обладает деловой репутацией добросовестного участника гражданского оборота в силу презумпции, установленной ГК РФ. Со временем, осуществляя тот или иной вид деятельнос- 
ти, участники гражданского оборота могут упрочить свою деловую репутацию по определенному направлению деятельности, при этом по другим направлениям, по которым предпринимательская деятельность не осуществлялась, у него останется все та же базовая деловая репутация добросовестного участника гражданского оборота, если не доказано иное. Также возможно, что по разным направлениям предпринимательской деятельности может сложиться разная деловая репутация.

Вместе с тем ни анализ законодательной практики, ни анализ научной литературы по данному вопросу не позволяют ответить на поставленный вопрос, что же имел в виду арбитражный суд, говоря об уровне деловой репутации, и как он должен доказываться. Уровень - это показатель величины, степень развития чего-либо. Степень развития деловой репутации достаточно тяжело определить, опять-таки, от чего этот уровень начинать отмерять. С учетом ранее принятых решений получается, что необходимо доказывать уровень сформировавшейся деловой репутации субъекта предпринимательства. В литературе не раз отмечалось, что понятие «сформировавшаяся деловая репутация» является оценочным и достаточно трудно доказуемым. По нашему мнению, измерить уровень деловой репутации вообще невозможно, и поэтому суд не должен обязывать доказать определенный уровень деловой репутации на момент ее нарушения.

C момента принятия Постановления Президиума ВАС РФ от 17 июля 2012 года прошло достаточно времени, чтобы было можно сделать ряд обобщающих выводов на базе принятых судебных актов по делам о защите деловой репутации юридического лица и взыскании компенсации за ее нарушение. Направление развития судебной практики, заданное указанным Постановлением Президиума ВАС РФ, в большинстве случаев привело к невозможности защитить в суде деловую репутацию и взыскать репутационный вред.

\section{Литература}

1. Постановление Пленума Верховного Суда РФ от 24 февраля 2005 г. №3 «О судебной практике по делам о защите чести и достоинства граждан, а также деловой репутации граждан и юридических лиц» // СПС Кронсультант Плюс.

2. Постановление Президиума ВАС РФ от 17 июля 2012 г. №17528/11 по делу №A4522134/2010 // СПС Консультант Плюс.

3. Определение Верховного Суда РФ от 26 октября 2015 г. по делу №307-ЭС 15-5345, А56-17708/2014 // СПС Консультант Плюс.

4. Постановление Тринадцатого арбитражного апелляционного суда от 29 августа 2018 г. №13АП-9781/2018 по делу №A5668012/201//. [Электронный ресурс] — Режим доступа: http://kad.arbitr.ru.

5. Решение Арбитражного суда СанктПетербурга и Ленинградской области 7 марта 2018 г. по делу №A56-68012/2017//. [Электронный ресурс] - Режим доступа: http://kad. arbitr.ru.

6. Гаврилов Е. Нереальная репутационная компенсация // ЭЖ-Юрист. — 2017. №36. - С. 3.

7. Мордохов Г. Ю. Деловая репутация: генезис, определение понятия, правовое регулирование // Право и экономика. — 2017. №8. - С. 26-32.

8. Пиеничникова Е.С. Профессиональная и деловая репутация как объекты личных неимущественных прав граждан // Проблемы современной науки и образования. 2016. — №30 (72). — С. 79-81.

9. Революция в секс-шопе. [Электронный ресурс] - Режим доступа: //https://www. kommersant.ru/doc/2145050.

10. Рудковский Э.И. Социокультурная среда, региональная идентичность и приграничное сотрудничество // Ученые записки УО ВГУ им. П.М. Машерова. - 2016. T.21. - С. 110-114.

11. Эрделевский A. О некоторых вопросах судебной защиты деловой репутации // СПС КонсультантПлюс. — 2018. 


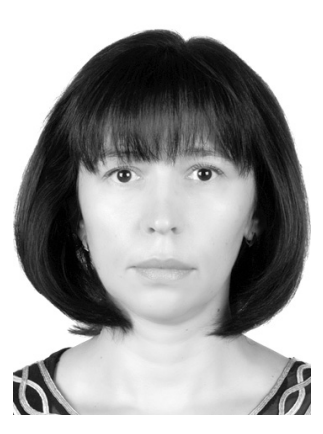

Записная Татьяна Валерьевна - кандидат юридических наук, доцент кафедры «Юриспруденция, философия и история» Южно-Российского государственного политехнического университета (НПИ) им. М.И. Платова, доцент кафедры «Медицинское право» Ростовского государственного медицинского университета Министерства здравоохранения Российской Федерации.

Zapisnaya Tatiana Valer'evna - Candidate of Juridical Sciences, Assistant Professor of the "Law, philosophy and history» Department of the South-Russian State Polytechnic University (NPI) named M.I. Platov, Assistant Professor of the «Medical law» Department of Rostov State Medical University.

346428, г. Новочеркасск, ул. Просвещения, 132

132 Prosveshcheniya st., 346428, Novocherkassk, Russia

Тел: +7 (8635) 25-57-71; e-mail: ztv061@yandex.ru 